\title{
EFFECT OF HOT DRYING ON THE CHEMICAL CONTENT AND COLOUR SENSORY QUALITY OF GINGER POWDER (ZINGIBER OFFICINALE)
}

\author{
Dao Nhat Quang, Vu Thi Huong, Hoang Quoc Tuan* \\ Department of Quality Management, School of Biotechnology and Food Technology, Hanoi \\ University of Science and Technology, No 1 Dai Co Viet Road, Hanoi, Vietnam \\ "Email: tuanhqibft@gmail.com; tuan.hoangquoc@hust.edu.vn
}

Received: 29 June 2015; Accepted for publication: 25 September 2015

\begin{abstract}
The main objective of this study was to investigate the effect of different temperature of hot air drying on the qualities of ginger powder included chemical content, colour parameters and colour sensory quality. The drying experiments were carried out at four air temperature of 50, 60,70 and $80{ }^{\circ} \mathrm{C}$. The colour parameters for colour change of the materials were quantified by the Hunter $L$ (whiteness/darkness), $a$ (redness/greenness) and $b$ (yellowness/blueness) system. These values were also used for calculation of total change $(\Delta E)$. A consumer preference test was conducted with 80 consumers to assess the colour quality of 04 ginger powders. The results showed that the decreasing of essential oils content at low drying temperature is higher than at high temperature. While the fats content was significantly decreased during drying at high temperature as compared with low temperature due to oxidation process of fat occurring at high temperature. The ginger powder was dried at high temperature showed a highly reduced content of protein and carbohydrate. Least Squares regression was used to determine the relationship between colour sensory scores of consumer taster and quantification of three Hunter parameters. In that, variable " $L$ " and " $b$ " could be distributed to increasing while variable " $a$ " contributory decrease the colour quality of ginger powder products. The zero-order, first-order and quadratic models were used to explain the colour change kinetics during hot drying ginger slices at $50^{\circ} \mathrm{C}$ and it was observed that $L, b$ and $a$ were fitted to quadratic model.
\end{abstract}

Keywords: ginger powder, colour, drying prediction model.

\section{INTRODUCTION}

Ginger is the rhizome of the plant Zingiber officinale. It is a tropical spice and cultivated in India, Vietnam, Japan, and China. Vietnam is one of the largest producer and consumer of ginger in the world. Ginger is cultivated in some mainly region such as Central Highlands, North Central Coastal and North Western Vietnam. It is generally harvested in the month of OctoberNovember [1]. The quality of fresh ginger as well as ginger powder produced in Vietnam is very good in terms of its aroma content [2]. But till now there is no proper post harvest processing of 
such good quality ginger powder. Open sun drying is a general practice and then is ground into a fine powder. Availability of sun being very much uncertain, sun drying is not effective in some region. Besides, there are other problems in sun drying like due to the slowness of the process and the exposure to the environment, the product gets contaminated from dust, insects etc. The weather being moist round the year, spoilage takes place very soon [3-5]. Therefore, more rapid, safe and controllable drying methods are required. The forced convection hot air drying is an effective method to produce a uniform, hygienic and attractive colours product rapidly. Therefore, a forced convective cabinet dryer has been developed to address such problem [6]. However, the colour of ginger product should be affected by hot temperature during drying. Besides the chemical composition, the colour also significantly affects on the sensory quality of products. Hence, it is crucial to determine and control the colour and chemical composition of the processed ginger. The changes of colour can be related with the degradation of nutritional compounds during processing that have important bioactive properties such as cupric ion reducing antioxidant capacity due to the decreasing of total phenolic content, ascorbic content and essential oil contents [7]. Standardized instrumental colour measurements corresponds to visual assessments of food colour and it is a critical objective parameter that can used as quality index (raw and processed foods), for the determination of conformity of food quality to specification and for analysis of quality changes as a result of food processing, storage and other factors. Several colour scales have been used to describe colour, those most used in food industry are the Hunter colour $L, a, b$ CIE system and the Munsell colour solid [8]. Maintaining the natural colour in processed and stored foods has been a major challenge in food processing. Most studies on changes in colour due to time and temperature treatments during food processing such as drying, heating, etc.

The drying behaviour of different materials was studied by many authors and several kinetic models have been established such as for pumpkin, sweet potato, carrot, apricot, etc... [911]. To the best of present authors' knowledge, no significant research on the changing of chemical composition and kinetics model for colour of ginger during hot drying as well as relation between colour and sensory evaluation has been reported in the literature. Therefore, the objectives of the present work are to study the effect of hot drying temperature on chemical composition and colour change kinetics and to find the relation between colour of ginger powder and sensory quality in order to predict the quality of ginger include chemical and colour changes with time by foregoing drying techniques.

\section{MATERIALS AND METHODS}

\subsection{Materials}

The rhizomes were purchased in a local market, washed and cut to samples of approximately $2-3 \mathrm{~mm}$ thickness. The experiments at 50,60,70 and $80{ }^{\circ} \mathrm{C}$ by keeping the air velocity fixed at $1.3 \mathrm{~m} / \mathrm{s}$. The airflow was measured by a portable, $0-15 \mathrm{~m} / \mathrm{s}$ range digital anemometer and adjusted by means of a variable speed blower. The drying process is stopped when the moisture content of the sample reached $6-7 \%$ (w.b). The drying experiments are replicated three times for each temperature and the average values are taken.

\subsection{Color measurements}


Sample colour was measured before drying and at pre-specified time interval during drying period by Hunter-Lab ColorFlex, A60-1010-615 model colormeter. This system uses three values ( $\mathrm{L}, \mathrm{a}$ and $\mathrm{b}$ ) to describle the precise location of a colour inside a three-dimensional visible colour space. The colorimeter was calibrated against standard white and green plates before each actual colour measurement. For each sample at least five measurements were performed at different positions and the measured values (mean values). The measurements were displayed in $\mathrm{L}$, $\mathrm{a}$ and $\mathrm{b}$ values which represents light-dark spectrum with a range from 0 (black) to 100 (white), the green - red spectrum with a range from -60 (green) to +60 (red) and the blue-yellow spectrum with a range from -60 (blue) to +60 (yellow) dimensions repestively.

Total colour difference was calculated using following equation, where subscript " 0 " refers to colore reading of fresh ginger. Fresh ginger was used as the reference and a larger $\Delta \mathrm{E}$ donates greater colour change from the reference material.

$$
\begin{gathered}
\Delta E=\sqrt{\left(L_{0}-L\right)^{2}+\left(a_{0}-a\right)^{2}+\left(b_{0}-b\right)^{2}} \\
\text { Chroma }=\left(\mathrm{a}^{2}+\mathrm{b}^{2}\right)^{0.5} \\
\text { Hue Angle }=\tan ^{-1}(\mathrm{~b} / \mathrm{a}) \\
B I=\frac{[100(x-0.31)]}{0.17} \\
\mathrm{x}=\frac{(a+1.75 L)}{(5.645 L+a-3.012 b)}
\end{gathered}
$$

where

where $\mathrm{L}$ is degree of lightness to darkness, $\mathrm{L}_{0}$ is initial value of $\mathrm{L}$, a is degree of redness to greennes, $a_{0}$ is initial value of $a, b$ is degree of yellowness to blueness and $b_{0}$ is initial value of $b$. Browning index (BI) represents the purity of brow colour and is considered as an important parameter associated browing [8].

\subsection{Chemical composition analysis}

The moisture, ash, fat and protein and oils content of the ginger powder and fresh ginger were determined by AOAC (2004) method [12].

\subsection{Consumer test}

A consumer preference test was conducted with 80 consumers to assess the colour quality of 04 ginger powders. Consumers were recruited from the Hanoi, Vietnam. Eligibility criteria included in the screener were used ginger powder, no affiliation market research Company, Vietnamese and age between 18 and 65. Consumers indicated their degree of liking of the products on the horizontal lines with "dislike extremely" on the left end and "like extremely" on the right end of line.

\subsection{Statistical analysis}

Statistical comparisons of the mean values for each experiment were performed by oneway analysis of variance (ANOVA), followed by the general linear model with repeated measured defined factors using SPSS 22 for Windows software. Significance was declared at P $\leq 0.05$. PLS regression was performed by XLSTAT (version, 2014). 


\section{RESULTS AND DISCUSSION}

\subsection{Effect of drying air temperature on the chemical content}

The fresh ginger and ginger powder were analyzed and their chemical compositions are shown in Table 1 . The fresh ginger contained moisture $80 \%$, protein $0.38 \%$, fat from $8.5 \%$, ash from to $6.7 \%$, essential oil from $2.5 \%$ and carbohydrate $2.9 \%$. The composition of fresh gingers in this study was more or less similar to those reported by several previous studied [13].

From Table 1, the ginger powder contained moisture from $5.080 \%$ to $5.315 \%$, protein $3.016 \%$ to $4.144 \%$, fat from $6.102 \%$ to $7.503 \%$, ash from to $8.726 \%$ to $9.104 \%$, essential oil $1.809 \%$ to $2.181 \%$ and carbohydrate from $79.337 \%$ to $81.807 \%$. These values are also similar to those found by some studied who reported [14].

The change in chemical content of different samples during drying is shown in Table 1. It was observed generally that the decreasing of essential oils content at low drying temperature is higher than at high temperature. The decreasing of essential oils is higher at low temperature could be due to increasing of drying time $\left(22 \mathrm{~h}\right.$ for $50{ }^{\circ} \mathrm{C}$ and $12 \mathrm{~h}$ for $\left.80{ }^{\circ} \mathrm{C}\right)$. While the fats content was significantly decreased during drying at high temperature as compared with low temperature due to oxidation process of fat occurring at high temperature. The ginger powder was dried at high temperature showed a highly reduced content of protein and carbohydrate. Drying ginger at a higher temperature appears to denature its protein and loss carbohydrate could be made alters its organoleptic attributes through loss of its colour. From this results obtained the temperature will significantly affect the qualities of ginger powder.

Table 1. Chemical Composition of fresh ginger and ginger powder at different drying air temperature.

\begin{tabular}{|c|c|c|c|c|c|c|}
\hline & Samples & Moisture (\%) & Essential Oils $^{\text {a }}$ & Fats $^{a}$ & Protein $^{a}$ & Carbohydrate $^{a}$ \\
\hline \multirow{2}{*}{$80^{\circ} \mathrm{C}$} & Fresh ginger & $80.332 \pm 0.109$ & $2.459 \pm 0.325$ & $8.417 \pm 0.224$ & $0.382 \pm 0.003$ & $2.936 \pm 0.657$ \\
\hline & Ginger powder & $5.315 \pm 0.194$ & $2.181 \pm 0.289$ & $6.102 \pm 0.015$ & $3.016 \pm 0.798$ & $79.337 \pm 1.347$ \\
\hline \multirow{2}{*}{$70^{\circ} \mathrm{C}$} & Fresh ginger & $81.149 \pm 2.835$ & $2.461 \pm 0.38$ & $8.615 \pm 0.616$ & $0.363 \pm 0.004$ & $3.121 \pm 0.657$ \\
\hline & Ginger powder & $5.289 \pm 0.552$ & $2.003 \pm 0.457$ & $7.015 \pm 0.163$ & $3.434 \pm 0.798$ & $80.402 \pm 1.347$ \\
\hline \multirow{2}{*}{$60^{\circ} \mathrm{C}$} & Fresh ginger & $81.268 \pm 2.149$ & $2.455 \pm 0.19$ & $8.467 \pm 0.513$ & $0.368 \pm 0.003$ & $2.914 \pm 0.657$ \\
\hline & Ginger powder & $5.023 \pm 0.135$ & $1.932 \pm 0.23$ & $7.309 \pm 0.215$ & $3.891 \pm 0.798$ & $81.004 \pm 1.347$ \\
\hline \multirow{2}{*}{$50^{\circ} \mathrm{C}$} & Fresh ginger & $80.385 \pm 1.895$ & $2.462 \pm 0.158$ & $8.458 \pm 0.487$ & $0.398 \pm 0.003$ & $2.986 \pm 0.657$ \\
\hline & Ginger powder & $5.080 \pm 0.449$ & $1.809 \pm 0.264$ & $7.503 \pm 0.351$ & $4.144 \pm 0.798$ & $81.807 \pm 1.347$ \\
\hline
\end{tabular}

a: \% dry matter;

\subsection{Colour and sensory evaluation of ginger powder.}

The result of consumer preference test was conducted with 80 consumers to evaluated of four ginger powder products showed that the product which was dried at $50{ }^{\circ} \mathrm{C}$ was the most preferable (mean 7.17), followed by sample was dried at $60{ }^{\circ} \mathrm{C}$ (mean 5.98), $80{ }^{\circ} \mathrm{C}$ (mean 4.71) and $70{ }^{\circ} \mathrm{C}(2.73)(\mathrm{p} \leq 0.05)$ (Figure 1). The significant differences observed in the colour evaluations indicate that the set provides a reasonable basis for the evaluation of possible relationship between three values ( $\mathrm{L}, \mathrm{a}$ and $\mathrm{b}$ ) and colour characteristics and/or colour evaluations. 
Based on the Hunter colour parameter which was analyzed by Hunter-Lab ColorFlex and preference scores of 04 ginger powder products, the results of PLSR analysis indicated the positive and negative correlations between Hunter colour parameter and specific sensory attributes. The validation coefficients of three colour values which regression models were developed as listed in Table 2. In that, both the weight vectors of $b$ values was positive correlated with sensory attributes (colour quality), while the others have negatively or positively correlated (Figs 2 and 3).

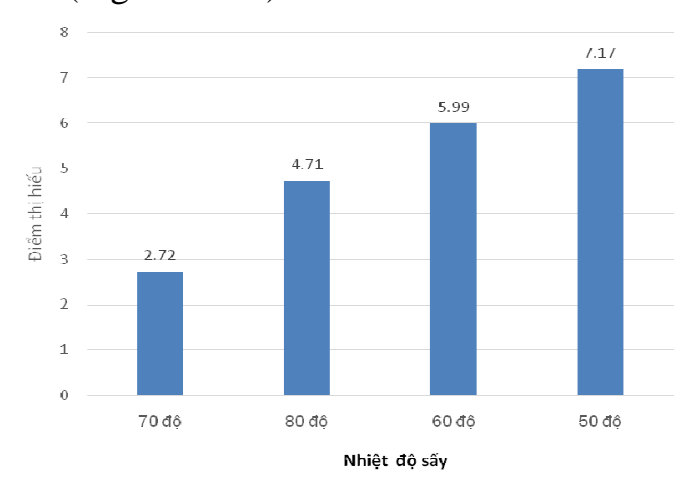

Figure 1. Preference scores and products.

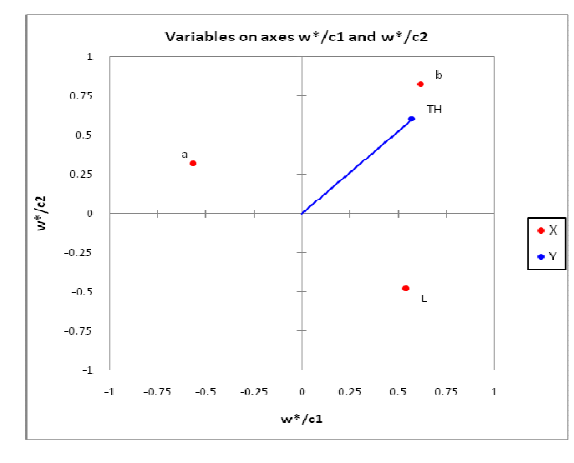

Figure 2. Consumer preference (Y) and Hunter colour parameter $(\mathrm{X})$ of ginger powder.

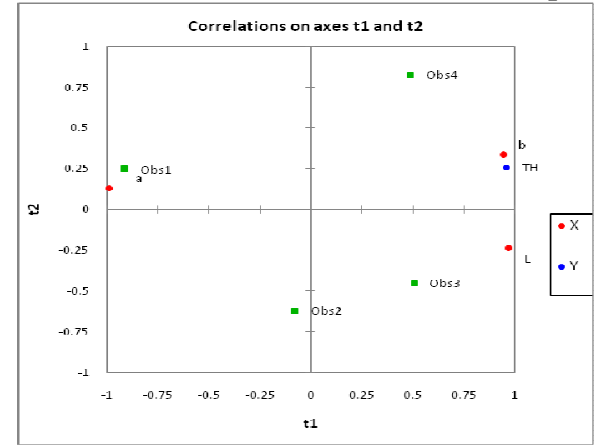

Figure 3. The correlations map on $\mathrm{t} 1$ and $\mathrm{t} 2$ of products (obs), Hunter colour parameter (X) and consumer preference (Y).

When considering the calibration sets, a good correlation between three values ( $\mathrm{L}$, a and $\mathrm{b}$ ) and colour quality ranking could be achieved as observed from a good determination coefficient $\left(\mathrm{R}^{2}\right)$ of 0.989 . The error rate of predictability of calibration model could be expressed from a term of root mean square error of estimation (RMSE), which was found at 0.17 . The good correlation of the reliable calibration model suggested that the complexity of sensory perception could be related directly to the three values ( $\mathrm{L}$, $\mathrm{a}$ and $\mathrm{b}$ ) by means of multivariate analysis. The low RMSE values of this model suggested that three values ( $\mathrm{L}$, a and $\mathrm{b}$ ) obtained from instrument methods provided sufficient correlation information to the colour sensory quality ranking.

Furthermore, compounds with high relevance for explaining dependent Y-variables were also identified from variable importance in the projection values (VIP). Large VIP values, more than 0.8 , are the most relevant for explaining the colour quality rankings of ginger powder and the compounds with VIP values greater than 0.8 were presented in Table 3 . It was found that key values contributing in creating the colour quality predictive model were composed of various Hunter colour parameter. 
Table 2. Correlation matrix of the variables (correlation matrix of $\mathrm{W}$ ).

\begin{tabular}{ccc}
\hline Variable & $\mathrm{w}^{* 1}$ & $\mathrm{w}^{* 2}$ \\
\hline $\mathrm{L}$ & 0.5443 & -0.4761 \\
$\mathrm{a}$ & -0.5675 & 0.3182 \\
$\mathrm{~b}$ & 0.6178 & 0.8227 \\
\hline
\end{tabular}

Table 3. Key values contributing to the construction of predictive model using Hunter colour parameter.

\begin{tabular}{ccc}
\hline Variable & VIP & $\begin{array}{c}\text { Standardized } \\
\text { coefficients }\end{array}$ \\
\hline $\mathrm{b}$ & 1.07 & 0.8498 \\
$\mathrm{a}$ & 0.98 & -0.1346 \\
$\mathrm{~L}$ & 0.94 & 0.0264 \\
\hline \multicolumn{3}{c}{ VIP: variable impotantce in the } \\
\multicolumn{3}{c}{ Projection }
\end{tabular}

All VIP values are higher than 0.8 , therefore a simplified model of favourable products was obtained (Eq.1).

$$
\mathrm{Y}=0.8498 * \mathrm{~b}-0.1346 * \mathrm{a}+0.0264 * \mathrm{~L}
$$

Equation of the model of favourable products showed that all there colour values could be significantly effect to colour quality ranking of ginger powder. In that, variable "L" and "b" could be distributed to increasing while variable "a" contributory decrease the colour quality of ginger powder products.

\subsection{Prediction Models for Colour Changes}

To investigate the effect of hot air on colour change kinetics of ginger slices during drying processing, air temperature of $50{ }^{\circ} \mathrm{C}$ was used for drying of constants amount of $1.5 \mathrm{~kg}$ fresh ginger. The values of $\mathrm{L}, \mathrm{a}, \mathrm{b}$ and total colour change $(\Delta \mathrm{E})$ obtained from the experimental data during hot air drying and model data are presented in Table 3.

Table 3. The changing of $\mathrm{L}$ value, a value and $\mathrm{b}$ value as function of drying time at $50{ }^{\circ} \mathrm{C}$.

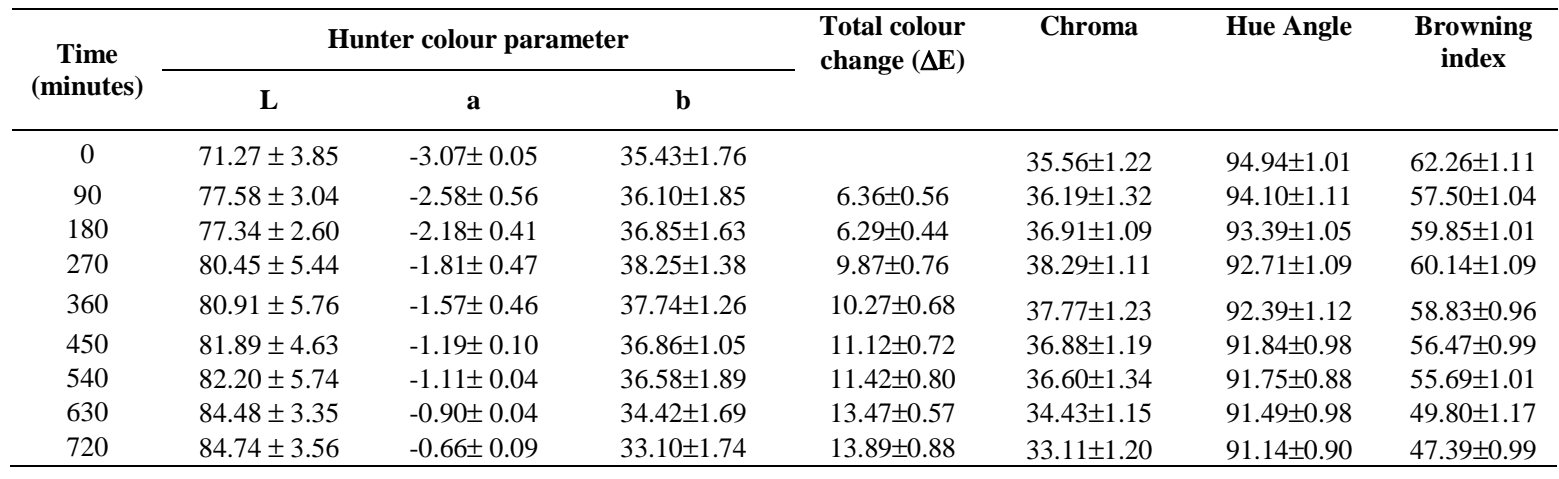

As can be seen from this figures, the $\mathrm{L}$ value increased with drying time. It have been stated that the change in brightness of dried samples, which increased from $71.27 \pm 3.85$ to $84.74 \pm$ 3.56 during hot air drying of ginger samples at $50{ }^{\circ} \mathrm{C}$. The "a" values were varied changed from $3.07 \pm 0.05$ to $-0.66 \pm 0.09$ as the drying time increased. Therefore, the colour of ginger sample trend to lose its greenness when drying time increased. While, the $b$ value increased at haft of drying time and then decreased to final drying time. The initial and final $b$ values were varied change from $35.43 \pm 1.76$ to $33.10 \pm 1.74$ as the time increased. The change of colour may be due to decomposition of pigment compounds, non-enzymatic Maillard reaction [15]. As a whole, 
the total colour change $(\Delta \mathrm{E})$ of ginger slices increased during hot air drying with drying time and ranged from $6.36 \pm 0.56$ to $13.88 \pm 0.88$ as drying time increased.

Table 4. Model summary, ANOVA and Coefficients of prediction model for colour changed.

\begin{tabular}{|c|c|c|c|c|c|c|}
\hline $\begin{array}{l}\text { Colour } \\
\text { Values }\end{array}$ & Model & Equation & $\begin{array}{c}\text { Adjusted } \\
\mathbf{R}^{2}\end{array}$ & $\begin{array}{c}\mathbf{p} \\
\text { (ANOVA) }\end{array}$ & \multicolumn{2}{|c|}{$\underset{\text { (Coefficient) }}{p}$} \\
\hline \multirow{6}{*}{$\mathrm{L}$} & \multirow{3}{*}{ Quadratic } & \multirow{3}{*}{$72.847+0.03 t-2.02 \mathrm{E}^{-05} \mathrm{t}^{2}$} & \multirow{3}{*}{0.903} & \multirow{3}{*}{0.000} & $t$ & 0.004 \\
\hline & & & & & $t^{2}$ & 0.040 \\
\hline & & & & & $\mathrm{C}$ & 0.000 \\
\hline & \multirow{2}{*}{ Linear } & \multirow{2}{*}{$74.378+0.016 \mathrm{t}$} & \multirow{2}{*}{0.850} & \multirow{2}{*}{0.000} & $\mathrm{t}$ & 0.000 \\
\hline & & & & & $\mathrm{C}$ & 0.000 \\
\hline & \multirow[t]{2}{*}{ Exponential } & \multirow[t]{2}{*}{$74.397 * \mathrm{e}^{(0.000 t)}$} & \multirow[t]{2}{*}{0.830} & \multirow[t]{2}{*}{0.000} & $\mathrm{t}$ & 0.000 \\
\hline \multirow{5}{*}{$\mathrm{a}$} & & & & & $\mathrm{t}$ & 0.001 \\
\hline & \multirow[t]{2}{*}{ Quadratic } & \multirow[t]{2}{*}{$-3.038+0.005 t-2.664 \mathrm{E}^{-06} \mathrm{t}^{2}$} & \multirow[t]{2}{*}{0.995} & \multirow[t]{2}{*}{0.000} & $t^{2}$ & 0.001 \\
\hline & & & & & $\mathrm{C}$ & 0.000 \\
\hline & \multirow[t]{3}{*}{ Linear } & \multirow{3}{*}{$-2.837+0.003 \mathrm{t}$} & \multirow{3}{*}{0.964} & \multirow{2}{*}{0.000} & $\mathrm{t}$ & 0.000 \\
\hline & & & & & C & 0.000 \\
\hline \multirow{6}{*}{ b } & & & & \multirow{3}{*}{0.000} & $\mathrm{t}$ & 0.000 \\
\hline & \multirow[t]{2}{*}{ Quadratic } & \multirow{2}{*}{$35.143+0.017 \mathrm{t}-2.76 \mathrm{E}^{-05} \mathrm{t}^{2}$} & \multirow{2}{*}{0.929} & & $t^{2}$ & 0.000 \\
\hline & & & & & C & 0.000 \\
\hline & \multirow[t]{2}{*}{ Linear } & \multirow[t]{2}{*}{$37.231-0.003 t$} & \multirow{2}{*}{0.098} & \multirow{2}{*}{0.214} & $\mathrm{t}$ & 0.214 \\
\hline & & & & & C & 0.000 \\
\hline & Exponential & $37.254 * \mathrm{e}^{(0.045 \mathrm{t})}$ & 0.108 & 0.204 & $\mathrm{t}$ & 0.204 \\
\hline
\end{tabular}

* C- Constant; $* \mathrm{t}$-time

Chroma, hue angle and Browning index (BI) were calculated by using equation (2) - (4) and the results are shown in Table 3. The values of hue angle, chroma and Browning decreased as a function of drying time. The hue angle value corresponds to whether the object is red, orange, yellow, green, blue, or violet. The initial hue angle of ginger slices was about $94^{\circ}$, which represents a colour in slightly green-predominantly yellow region (hue angle between $90-180^{\circ}$ ) of the colour solid dimensions. Upon heating, the hue angle increased, shifting towards the more cyan region.

For the mathematical predicting of colour change of ginger, quadratic, zero-order and firstorder models were used. It was observed that $\mathrm{L}, \mathrm{a}$ and $\mathrm{b}$ values were fitted to the quadratic model. The estimated prediction parameters of these models and the statistical values of coefficients of determination adjusted $R^{2}$ as well as significant values are represented in Table 4 .

\section{CONCLUSION}

Results obtained from this research show that qualities of ginger powder is affected by temperature of hot air drying. It was observed generally that the decreasing of essential oils content at low drying temperature is higher than at high temperature. While the fats content was significantly decreased during drying at high temperature as compared with low temperature due to oxidation process of fat occurring at high temperature. The ginger powder was dried at high temperature showed a highly reduced content of protein and carbohydrate. 
On the basis of the Hunter colour parameter included L, a and b, a model (determination coefficient (R2) of 0.989 , and root mean square error of estimation (RMSE) of 0.17 was constructed to predict the colour quality of ginger powder. From the result obtained in this study, the $\mathrm{L}$, $\mathrm{a}$ and $\mathrm{b}$ values profiling by instrument methods in the combination with sensory and multivariate data analysis should be a useful reference for colour quality prediction of ginger powder.

The colour change of ginger slices using the $\mathrm{L}$, $\mathrm{a}$ and $\mathrm{b}$ system totally explained the real behavior of ginger samples undergoing hot air drying. The final values of $\mathrm{L}, \mathrm{a}, \mathrm{b}$ and total colour change $(\Delta \mathrm{E})$ were influenced by hot air drying. The zero-order, first-order and quadratic models were used to explain the colour change kinetics and it was observed that $\mathrm{L}, \mathrm{b}$ and a were fitted to quadratic model. The $\mathrm{a}, \mathrm{L}$ and $\Delta \mathrm{E}$ increased; on the other hand, $\mathrm{b}$ decreased when the air temperature was increased.

\section{REFERENCES}

1. Vasala P. A. - Ginger, in Handbook of Herbs and Spices (Second edition), K.V. Peter, Editor., Woodhead Publishing (2012) 319-335.

2. Van Beek T. A, Hoang V. P., and Bui T. Y - Investigation of the essential oil of Vietnamese ginger, Phytochemistry 26 (11) (1987) 3005-3010.

3. Phoungchandang S. and Saentaweesuk S. - Effect of two stage, tray and heat pump assisted-dehumidified drying on drying characteristics and qualities of dried ginger, Food and Bioproducts Processing 89 (4) (2011) 429-437.

4. Gümüşay Ö. A - Drying effects on the antioxidant properties of tomatoes and ginger, Food Chemistry 173 (2015) 156-162.

5. Eze J. I. and Agabo K. E. - Comparative studies of sun and solar drying of peeled and unpeeled ginger, American Journal of Scientific and Industrial Research 2(2) (2011) 136 143.

6. Law C. L., Chen H. H. H. and A. S. Mujumdar - Food Technologies: Drying, in Encyclopedia of Food Safety, Y. Motarjemi, Editor, Academic Press: Waltham (2014) 156-167.

7. Ding S. H., An K. J., Guo Y. H., and Wang Z. F. - Effect of drying methods on volatiles of Chinese ginger (Zingiber officinale Roscoe), Food and Bioproducts Processing 90 (3) (2012) 515-524.

8. Choudhury A. K. R. Chapter 7 - Using instruments to quantify colour, in Principles of Colour and Appearance Measurement, A.K.R. Choudhury Editor, Woodhead Publishing (2014) 270-317.

9. Toğrul İ. T. and Pehlivan D. - Modelling of drying kinetics of single apricot, Journal of Food Engineering 58 (1) (2003) 23-32.

10. Doymaz İ. - Convective air drying characteristics of thin layer carrots, Journal of Food Engineering 61 (3) ( 2004) 359-364.

11. Diamante L. M. and P. A. Munro - Mathematical modelling of hot air drying of sweet potato slices, International Journal of Food Science \& Technology 26 (1) (1991) 99-109.

12. AOAC, Official method of analysis. 12 th Ed. Association of Official Agricultural Chemists, Washington, D. C. USA (2004). 
13. Prabhakaran Nair K. P. Chapter 16 - The Chemistry of Ginger, in The Agronomy and Economy of Turmeric and Ginger, Elsevier: Oxford. (2013) 293-337.

14. Prabhakaran Nair K. P. Chapter 20 - Ginger Nutrition, in The Agronomy and Economy of Turmeric and Ginger, Elsevier Oxford (2013) 401-408.

15. Rizzi G. P. - The Maillard Reaction in Foods, in Maillard Reactions in Chemistry, Food and Health, T. P. Labuza, et al., Editors. Woodhead Publishing, (2005) 11-19.

\title{
TÓM TẮT
}

\section{ẢNH HƯỞNG CỦA SÂY KHÍ NÓNG LÊN THÀNH PHẦN HÓA LÍ VÀ CHÂT LƯỢNG CẢM QUAN MÀU SĂC CỦA GỬNG BỘT (Zingiber officinale)}

\author{
Đào Nhật Quang, Vũ Thị Hường, Hoàng Quốc Tuấn* \\ Bộ môn Quản lý Chất lương, Viện Công nghệ sinh hoc - Công nghệ thưc phẩm, \\ Truoơng đại học Bách Khoa Hà Nội, Số 1 Đại Cồ Việt, Hà Nội, Việt Nam \\ "Email: tuanhqibft@gmail.com; tuan.hoangquoc@hust.edu.vn
}

Mục tiêu chính của nghiên cứu này là đánh giá sự ảnh hưởng của nhiệt độ sấy trong phương pháp sấy khí nóng lên chất lượng của bột gừng bao gồm thành phần hóa học, thông số màu và chất lượng cảm quan màu. Thí nghiệm sấy được tiến hành ở bốn mức nhiệt độ gồm 50 , 60,70 và $80^{\circ} \mathrm{C}$. Thông số màu Hunter gồm 3 giá trị $L, a, b$ được sử dụng để xác định màu của gừng lát trong quá trình sấy và gừng bột sản phẩm. Các giá trị này cũng được sử đụng để tính toán giá trị sự thay đổi màu tổng thể $(\Delta E)$. Phép thử cảm quan thị hiếu trên 80 người được sử dụng để đánh giá chất lượng cảm quan màu của 04 mẫu gừng bột. Kết quả cho thấy sự suy giảm hàm lượng tinh dầu của mẫu sấy ở nhiệt độ thấp cao hơn so với mẫu sấy ở nhiệt độ cao. Trong khi đó, thành phần chất béo suy giảm đáng kể đối với mẫu sấy ở nhiệt độ cao so với mẫu sấy ở nhiệt độ thấp do quá trình oxi hóa chất béo xảy ra trong điều kiện nhiệt độ cao. Nhiệt độ cao ảnh hưởng đáng kể đến sự suy giảm hàm lượng protein và carbohydrate trong bột gừng. Phương trình hồi quy tương quan được sử dụng để xác định mối tương quan giữa điểm cảm quan thị hiếu màu và các giá trị màu. Trong đó, giá trị $\mathrm{L}$ và $\mathrm{b}$ góp phần làm tăng giá trị cảm quan, còn giá trị $\mathrm{a}$ góp phần làm giảm giá trị cảm quan màu sắc của sản phẩm. Mô hình động lực bậc 0 (zeroorder), bậc 1 (first-order) và bậc 2 (quadratic) được sử dụng để xây dựng mô hình dự báo sự thay đổi mẫu sấy ở $50^{\circ} \mathrm{C}$ và kết quả cho thấy mô hình bậc hai là phù hợp nhất để dự báo sự biến đổi màu sắc trong quá trình sấy gừng ở nhiệt độ sấy $50^{\circ} \mathrm{C}$.

Tù khóa: gừng, mã màu sắc, mô hình dự báo. 